\title{
Development of organic agriculture: case of Latvia
}

\author{
Tatjana Tambovceva \\ Faculty of Engineering Economics and Management \\ Riga Technical University \\ Riga, Latvia \\ tatjana.tambovceva@rtu.lv
}

\author{
Andrejs Tambovcevs \\ Faculty of Computer Science and Information Technology \\ Riga Technical University \\ Riga, Latvia \\ ata2000@inbox.lv
}

Received: April 15, 2019. Revised: May 2, 2021. Accepted: September 30, 2021. Published: November 15, 2021.

\begin{abstract}
Agriculture is one of the main sectors which many believe should be sustainable, that is, ecologically sound, economically viable, and socially responsible. While conventional agriculture is driven almost solely by productivity and profit, sustainable agriculture integrates biological, chemical, physical, ecological, economic and social sciences in a comprehensive way to develop new farming practices that are safe and do not degrade our environment. Sustainability in rural production system can only be achieved if it can suitably satisfy the local requirement as well as the outside demand with the changing time. This paper reviews the concepts of organic agriculture and examines its development in Latvia.
\end{abstract}

Keywords - organic farming, organic agriculture, sustainable agriculture, sustainable development, rural development

\section{INTRODUCTION}

The concept of sustainability, which originally referred to environmental consequences of human activities, has been widely discussed not only at the national but at the global level, as well as in particular economic sectors. Agriculture is closely connected with the development of the whole country, especially rural regions and food production. Rural areas are a source of the most important natural resources and ecosystem services, and environment for work and recreation, and a depository of the diversity of cultural and historical heritage. Sustainability in the context of agriculture has a special significance. Agriculture is one of the main sectors which many believe should be sustainable, that is, ecologically sound, economically viable, and socially responsible. This is so because agriculture provides basic human needs, and in most developing countries it is an important source of national income, foreign trade and employment. Agriculture is also a multi-functional sector which is closely related to the environment. Agriculture is one of the biggest environmental polluters and destroyers. Agricultural production systems pollute soil and water with agro-chemicals, reduce biodiversity, lead to degradation, desertification, erosion of soils and, in many cases, result in poorly structured, monotonic agricultural landscapes.

The image of agriculture and rural areas will be changed it the future due the evolutionary nature of their development caused by the need of adapting to a changing social and economic reality [18]; [26]. Because of the close linkage of agriculture to natural resources it is important to design such a model for rural development and agriculture, which will combine economic development in balance and harmony with social expectations and requirements of natural environment [3].
Agricultural sector has always been one of the important sectors in Latvia's economy constituting $1.6 \%$ of the Gross Domestic Product on average or LVL 203 million in 2011. They are a place of life and work for a large part of society, which produces food and raw materials used in industry. The aim of the research is to investigate the concepts of sustainable agriculture and analyse trends of development of sustainable agriculture in Latvia. In order to achieve the aim the authors have set up the following tasks:

- to analyse historical development of sustainable agriculture from the political and economic aspects;

- to analyse the current situation of sustainable agriculture in Latvia.

The research is based on the recent theories of leading scientists in the field of sustainable agriculture as well as on the statistical data provided by EUROSTAT (Statistical Office of the European Communities), IFOAM (International Federation of Organic Agriculture Movements), Ministry of Agriculture of Latvia (MA) and CSB (Central Statistical Bureau of Latvia). Authors based the analysis of the development of the sustainable agriculture in Latvia on the previous research held in 2009 [30] and comparing with the nowadays situation.

\section{RESULTS OF RESEARCH}

\section{A. Sustainability and sustainable agriculture}

Sustainability has been an exceedingly popular word over recent years, used for almost every activity in human life. The term "sustainable development" was first defined in 1987 by the Brundtland Commission, formally the World Commission on Environment and Development. The Commission defined sustainable development as: "development that meets the needs of the present without compromising the ability of future generations to meet their own needs." This concept was then enhanced by the United Nations Conference on Environment and Development at the Earth Summit, Rio de Janeiro, in 1992. From that time, sustainable development became a key issue in political and scientific bodies. A comprehensive definition of sustainability as the attempt to balance economic, social, and environmental goals might be as follows: "improving the quality of human life while living within the carrying capacity of the supporting ecosystem".

Ecological philosophy of agriculture has existed for centuries, but the organic movement could begin only once an alternative to them existed. Lack of food after the Second World War motivated to look for new possibilities to increase 
yields in agriculture, which stimulated industrialisation and intensification of agricultural production [6].

Agricultural activities are often based on individual producer's decisions and on their attitudes, knowledge and level of technology. They are however also based on political and economic considerations, attitudes and opinions from the society. Thus, continuously updated scientifically based knowledge, both from an environmental, social and economic view, need to be disseminated and applied with a much increased ambition. Technological facts may be well known, but still strong social and economic reasons and pressure from outside to make short term profits hinders the appropriate application of relevant measures.

Technologies used in agriculture have changed dramatically in the 20th century: they became profitable to replace farm labour with machinery, to protect harvest from pests with chemical pesticides, and to increase soil fertility by chemical fertilisers. New forms of agriculture brought some advantages: labour and soil productivity increased, and food became abundant and cheap for the consumer; the labour force which left agriculture could be productive in other areas of society, and thus increase the total wealth. But there were also problems associated with these developments: in many cases modern agricultural technologies had negative impact on the natural environment, with the massive build-up of nutrient surpluses and intensive use of pesticides; societies became very concerned in respect of animal welfare in industrial production; the loss of heritage landscapes, and biodiversity.

Sustainable agriculture could involve two approaches. The first approach is that agriculture should sustain itself over a long period of time by protecting its productive resources, e.g. maintaining soil fertility, protecting groundwater, developing renewable energies, and finding solutions to adapt farming systems to climate change. This first approach considers the farming system as a closed area. The second approach is to consider that agriculture also has to contribute to the sustainability of large territories and social communities. Accordingly, agriculture should help urban areas to manage wastes, e.g., by recycling urban sewage sludge, developing rural employment, and offering a rural landscape for urban people. This second approach has wider goals and does not separate rural and urban areas. To conclude, the vagueness of the concept of sustainable development and sustainable agriculture is strength because it does not restrict the research field too much, and, in turn gives freedom to scientists to explore wide, unknown domains.

Sustainable agriculture is shown by many reports ([12]; [13]; [14]; [16]; [17]; [19]; [25]; [27]; [31] etc.). Much knowledge has been acquired concerning the processes involved in the conversion from conventional to organic agriculture in various regions of the world (mainly Europe, Australia, New Zealand, and North America). Many authors and organisations worldwide give their own definition of sustainable agriculture. Some authors consider sustainable agriculture as a set of management strategies addressing the main societal concerns about food quality or environment protection [10]. Other authors focus on one main factor of sustainability; for instance, flexibility, which is the adaptive capacity of agriculture to adapt for future changes [11]. Other authors focus on the ability of agricultural systems to maintain crop productivity over the long term [15]. Overall, all authors agree on the occurrence of three approaches to the concept of sustainable agriculture: environmental, economic and social approaches. In other words, agricultural systems are considered to be sustainable if they sustain themselves over a long period of time, that is, if they are economically viable, environmentally safe and socially fair.

The farm is the smallest productive and economic entity in agriculture. Influenced by the agricultural policy and market conditions, the decisions on what to produce and how to produce are made on the farm. Sustainable agriculture describes one possible relationship between the use of natural resources and the needs of the market and tries to balance ecological capacities and economic interests.

A sustainable farm must achieve both economic and environmental goals without losing sight of social aspects (such as family quality of life, human health, relationships with community, farmer's education and skills, etc.) [4].

The new paradigm of sustainable development in agriculture is based on respecting the following principles [28]:

- The principle of health: "Organic Agriculture should sustain and enhance the health of soil, plant, animal, human and planet as one and indivisible".

- The principle of ecology: “Organic Agriculture should be based on living ecological systems and cycles, work with them, emulate them and help sustain them".

- The principle of fairness: “Organic Agriculture should build on relationships that ensure fairness with regard to the common environment and life opportunities".

- The principle of care: "Organic Agriculture should be managed in a precautionary and responsible manner to protect the health and well-being of current and future generations and the environment".

Unfortunately, many obstacles exist on the way to achieving a more sustainable agriculture. Among them we can mention:

- the domination of short term (market and profit oriented) interests instead of long-term ones;

- export oriented economy instead of providing selfsufficiency at the local level and exporting the extra amount of products;

- the globalization of the economy with the dominance of transcontinental companies which are selling pesticides, seeds, machines etc.;

- the lack of the evaluation system for the cost of natural resources in the modern market oriented economy.

But in the same time these obstacles and other factors serves as incentives for a transition to a more sustainable farming system: 
- high and increasing prices for non-renewable sources of energy (natural gas, petrol, coal) and their derivates synthesized in industrial conditions (mineral fertilizers, pesticides);

- the profit in permanent decrease for farmers because of high prices for external inputs;

- increased levels of degradation and pollution of the environment;

- higher risks for the health of producers and consumers.

Organic agriculture is an agricultural system that seeks to provide consumers with fresh, tasty and authentic food while respecting natural life-cycle systems. It means that organic agriculture is a production system that sustains the health of soils, ecosystems and people. It relies on ecological processes, biodiversity and cycles adapted to local conditions, rather than the use of inputs with adverse effects. Organic agriculture combines tradition, innovation and science to benefit the shared environment and promote fair relationships and a good quality of life for all involved. [23]

To achieve this, organic agriculture relies on a number of objectives and principles, as well as common practices designed to minimise the human impact on the environment, while ensuring the agricultural system operates as naturally as possible.

Typical organic agriculture practices include:

- wide crop rotation as a prerequisite for an efficient use of on-site resources;

- very strict limits on chemical synthetic pesticide and synthetic fertiliser use, livestock antibiotics, food additives and processing aids and other inputs;

- absolute prohibition of the use of genetically modified organisms;

- taking advantage of on-site resources, such as livestock manure for fertiliser or feed produced on the farm;

- choosing plant and animal species that are resistant to disease and adapted to local conditions;

- raising livestock in free-range, open-air systems and providing them with organic feed;

- using animal husbandry practices appropriate to different livestock species. [24]

Organically produced food products are obtained using natural biological methods, avoiding the use of artificial pesticides and fertilizers (save energy used for production, avoid the use of chemicals in weed, pest and microorganism control). The process is going on promoting natural feeding of plants from the water, air and soil with the help of solar energy and microorganisms.

Organic agriculture precondition is healthy soil, which is a natural and living unit with diverse flora and fauna. Only healthy soil can produce healthy plants resulting in healthy food for humans and feed for animals.
Reduction in environmental pollution is achieved through reduced cattle numbers and decreased application of farmyard manure per unit of land area. For nature conservation, local plant and animal breeds are recommended as they are best compatible with the local microorganisms providing food most suitable to local population.

Builds the social capital of rural areas, being knowledge intensive, rather than capital and resource-intensive, it utilizes traditional knowledge and promotes farmer-to-farmer exchange. It provides tools for inspection and control, like Internal Control and Participatory Guarantee Systems that strengthen social organization and empower rural communities.

\section{B. Organic agriculture and farming in Latvia: a background}

Latvia has a rich history in agriculture and farming. Before the beginning of World War II, its farmers had successfully competed with European agro-producers. Karlis Ulmanis, the first Prime Minister of Latvia, studied agriculture in Switzerland, Germany and the U.S. and taught agriculture briefly upon his return to the country. K. Ulmanis can be credited with increased efficiency of the Latvian farms in those days. In the late 1930s there were 16 regular steam-ship routes from the Riga, Ventspils and Liepaja ports to major European destinations, such as London, Bremen, Hamburg and Stockholm. Latvian butter and bacon were the main exports to the West, as well as to the Russian market.

During Soviet times the small individual farms were replaced by the much larger state, or collective farms. By the end of the 1950s the consolidation of independent homesteads was almost complete, with over 90 percent of the farms turned into the "kolhozs". [5]

Intensive agriculture has different influence on environment than organic farming. The most widespread impacts of intensive agriculture on nature are soil degradation, pollution and erosion on the local scale, fresh water shortage, problems with food security and climate change on the global scale. These problems motivated farmers to look for other ways of farming.

After regaining the second independence in 1991, agricultural output in Latvia decreased by $40 \%$ in the result of land reform and structural changes in 2011 compared with 1990. However, we can see in Latvia also positive development trends, as the agricultural industry's contribution to gross domestic product (GDP) and the export of agricultural products increased in the period since 2000. The share of agriculture, hunting, and forestry in the total value added reached $11 \%$ in 2011 compare with 2010 . Labour productivity in the agricultural industry slowly increases owing to investments, it still lags behind other sectors of the national economy. There were more than 83 thousand farms in 2011. The majority are small farms in Latvia, the annual turnover of which does not exceed EUR 15 thousand. The number of such farms was more than 79 thousand or $95 \%$ of their total number. But usually these farms are not competitive in the single European market.

Currently, the Latvian agricultural sector is fully private. Farming is one of the main economic activities in the rural 
areas. Many farms are owned and operated by a single family that relies on agricultural output for all of its income.

The farming sector is largely composed of the small farms cultivating grain, potatoes, rapeseed, fruits and berries as well as producing milk, pork, poultry, veal and beef. The demand for the domestically produced agricultural goods is constantly growing. Many Latvians have fully embraced the global trend of living healthier and greener, based on supporting natural farming methods.

Organic farming is an agricultural system based on the principles of minimizing the human impact on environment, at the same time ensuring as natural as possible functioning of the agricultural system. These principles have been defined in the Council Regulation 2092/91 on organic production of agricultural products and indications referring there to on agricultural products and foodstuffs, Council Regulation $834 / 2007$ on organic production and labelling of organic products and repealing Regulation (EEC) No 2092/91.

Organic farming, one of the most promising export-oriented industries in Latvia going forward, has experienced the modernization of agricultural equipment that resulted in the steady increase of farming productivity. The implementation of EU-regulated quality inspection systems, as well as European Union and Latvian government investments, have stimulated the development of all agricultural sub-sectors including crop and livestock production.

The additional funding which became available since Latvia's accession to the EU in 2004 resulted in diversification and modernization of farming methods and practices as well as in the growth of Latvian agricultural exports. Main export destinations, according to the Central Statistical Bureau of Latvia, are Lithuania, Estonia, Russia and France for cheese and curd, Estonia, Italy and Germany for butter. Since fostering international contacts is the foundation of the modern business development model, network-building activities cannot be suspended, even in today's challenging economic conditions. Though the impact of the global economic crisis has been felt across every industry in the Baltic region, Latvian farmers are focusing on maintaining their presence in the traditional markets, as well as exploring new export destinations.

As a consequence, there has been an increase in the number of farm markets and organic produce stores offering a variety of quality products from the local farms and fields. There typically is a higher cost associated with bio-farming: organic feed for cattle and other livestock can cost twice as much as the conventional feed, while limiting the use of agrochemicals and relying on natural farming methods translates into lower production outputs. Last year, the share of organically cultivated land in Latvia was still less than 10 percent of the total farming area, but the sector analysts forecast sustainable development of this sector going forward. Over 4,000 organic farms in the country have different levels of certification and a large number of the Vides Veselības Saimes (Nature Friendly Households) are participating in the programs organized by the Association of Latvian Organic Agriculture that was founded in 1995. [5]

Even though the benefits of consuming organic versus conventional is subject to debate, generally, many Latvians are willing to pay premiums for the quality associated with the natural-grown products. Smaller local markets have effective quality control mechanisms that are benefiting the customers in the long run. There is a really small community of farmers here, and the customers know each and every one of them personally. As soon as the quality goes down, people vote with their feet, and since the news spreads really fast around here, I have to make sure that my produce is top-notch every time.

\section{Development of organic farming in Latvia}

Agriculture is one of the most important economic sectors in Latvia. Agricultural land occupies 39\% of Latvia's territory. It is the biggest user of agricultural land as well as the factor determining the quality of the rural landscape and environment. The development of the sector accelerates year-by-year, yet the contribution of agriculture to the gross domestic product is decreasing against the background of more rapidly growing value added of other sectors.

Analysis of the number of employed persons in agriculture shows increasing by $11 \%$ in 2012 compare with 2011. In Table 1 authors collected information about gross domestic product in agriculture and its share in the structure of gross domestic product in period from 2005 to 2011 years.

Organic farming is a uniform agricultural and food production system that provides optimal healthy and productive existence of inter-related elements of the ecosystem - soil, plants, animals and people. Production techniques are based on maintaining of a sustainable ecosystem, creating a maximum closed production cycle, fully excluding use of synthetically produced fertilizer and pesticide, minimizing the potential for contamination of the environment. The result of organic farming is not only healthy food, but also a sustainable natural environment, which ensures high quality of life not only humans but also plants and animals.

The development of organic farming in the country was promoted substantially by rural development measures of the Latvian government and the European Union after the accession to the EU. First group of farmers began to work with organic methods in the Liepāja district, then in other parts of Latvia (Cēsis, Ogre, Gulbene, etc.).

TABLE I. GROSS DOMESTIC PRODUCT IN AGRICULTURE AND ITS SHARE IN THE STRUCTURE OF GROSS DOMESTIC PRODUCT IN $2005-2011$

\begin{tabular}{|l|l|l|l|l|l|l|l|}
\hline & \multicolumn{1}{|c|}{$\mathbf{2 0 0 5}$} & \multicolumn{1}{|c|}{$\mathbf{2 0 0 6}$} & \multicolumn{1}{|c|}{$\mathbf{2 0 0 7}$} & \multicolumn{1}{|c|}{$\mathbf{2 0 0 8}$} & \multicolumn{1}{|c|}{$\mathbf{2 0 1 0}$} & \multicolumn{1}{|c|}{$\mathbf{2 0 1 1}$} \\
\hline GDP in actual prices, thous. LVL & 9000348 & 11126574 & 14720651 & 16084678 & 13070448 & 12784137 & 14275231 \\
\hline $\begin{array}{l}\text { Value added of agriculture and hunting at } \\
\text { actual prices, thous. LVL }\end{array}$ & 198514 & 215948 & 250651 & 248205 & 205045 & 215732 & 203245 \\
\hline $\begin{array}{l}\text { Contribution of value added of agriculture } \\
\text { and hunting to GDP at current prices, \% }\end{array}$ & 2.2 & 1.9 & 1.7 & 1.5 & 1.6 & 1.7 & 1.6 \\
\hline
\end{tabular}


Organic farming in Latvia developed considerably since its beginnings in 1989. Growth has been triggered by two activities:

1. The implementation of an inspection system according to EU regulation 2092/91 in 2001;

2. The implementation of an action plan in the country in 2003 that stimulated farmers' interest in converting to the organic system.

Local organic farming organizations cooperated and established an association in 1995. In 2003, the government accepted the Organic Farming Development Programme. Then, the Latvian Organic Farming Organisation joined the International Federation of Organic Agriculture Movements (IFOAM).

In 1998, the concept of organic farming was included in the state legislation. From that time, organic farming started to develop. Organic agriculture in Latvia is based on:

- efficient use of resources available on the farm, for instance, using of locally grown forage, effective utilization of manure, etc;

- selection of plant and animal varieties adaptable to the local conditions, thus, being disease-resistant;

- growing different kind of crops in pre- planned succession for the most efficient usage of the available resources;

- strict limits on using chemically synthesized pesticides, artificial fertilizers, antibiotics, feed nutrition enhancers, processing aids and other raw materials;

- prohibition of the use of genetically modified organisms;

- livestock farming system with the cattle grazing on pastures and their provision with organic livestock feed;

- livestock farming considering the needs of different livestock breeds.

The objectives of organic farming are the following:
- to ensure sustainable production of high-quality healthy food (instead of concentrating on maximizing yield), while maintaining crop and livestock diversity and preserving the environment (including plants, animals, soil, water and air);

- to ensure the fulfilment of requirements for livestock welfare (providing the animals with access to daylight, air, clean water, natural pastures and sufficient space, etc.);

- to use direct solar energy more efficiently and, as much as possible, to reduce use of fossil energy.

Opponents of organic farming declare that there is a threat of famine in the world and organic farms with low yield capacity cannot fight it. However, research shows that in many unfavourable conditions organic farming is more successful than intensive agriculture. Urs Niggli from the organic farms' certification organisation Research Institute of Organic Agriculture FiBL, Switzerland, said that in the regions with favourable conditions for agriculture the decrease of yield might be from 0 till $20 \%$, but in the regions with broken humidity regime, productiveness grows for $116 \%$. [22]

In Latvia there were 39 organic farms registered in 1998, 550 farms - in 2003, 1043 - in 2004. The number of organic farms and the organic area increased rapidly in 2005 and 2006, and between 2003 and 2004 it even almost doubled. At the beginning of 2012, the number of farms engaged in organic farming in Latvia decreased by $3 \%$ in comparison with the end of 2010. Total number of organic farms in Latvia in period from 1998 to 2011 is shown in Figure 1.

Despite the fact that the number of farms is large enough, however, these are small companies and their number is not sufficient.

Today approximately 4000 farms are managed with organic methods. This number constitutes to $5 \%$ of the total number of the farms in the country, and the organic farming covers $8 \%$ of the agricultural lands. The largest number of organic farms is located in districts Cēsis (330 farms), Madona (220 farms) and Alūksne (156 farms). Figure 2 depicts organic farming areas size (ha).

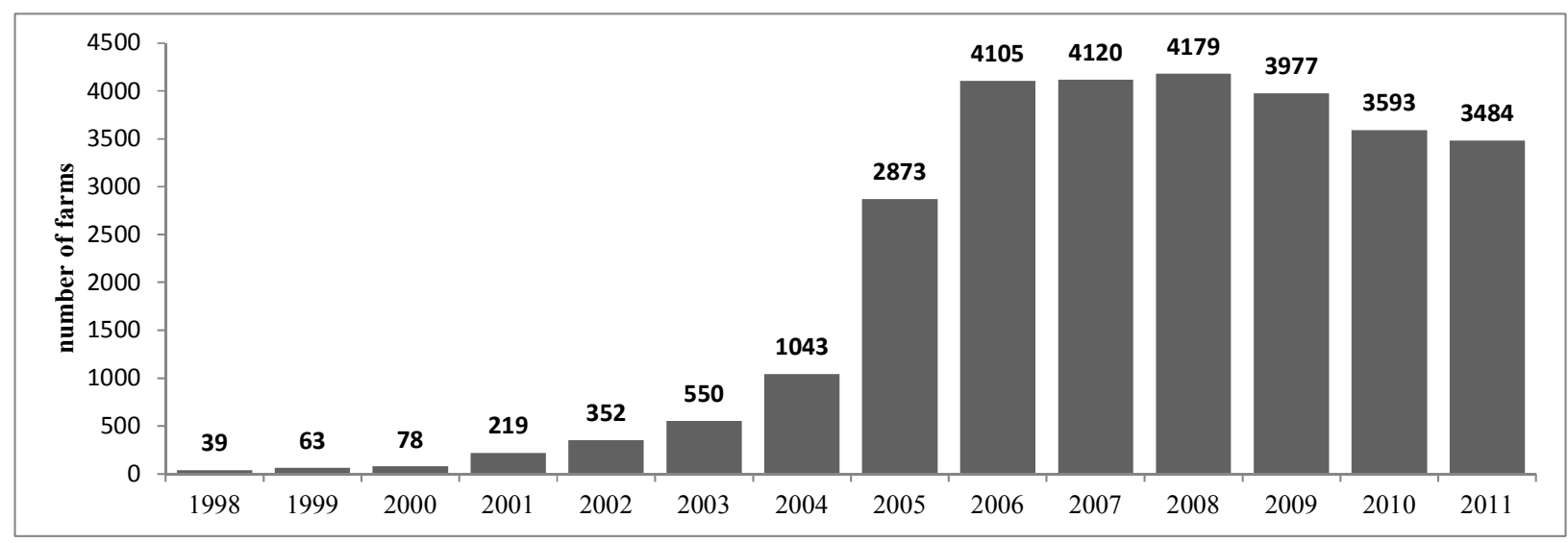

Fig. 1. Number of organic farms in 1998 - 2011 [prepared by authors using [32]] 


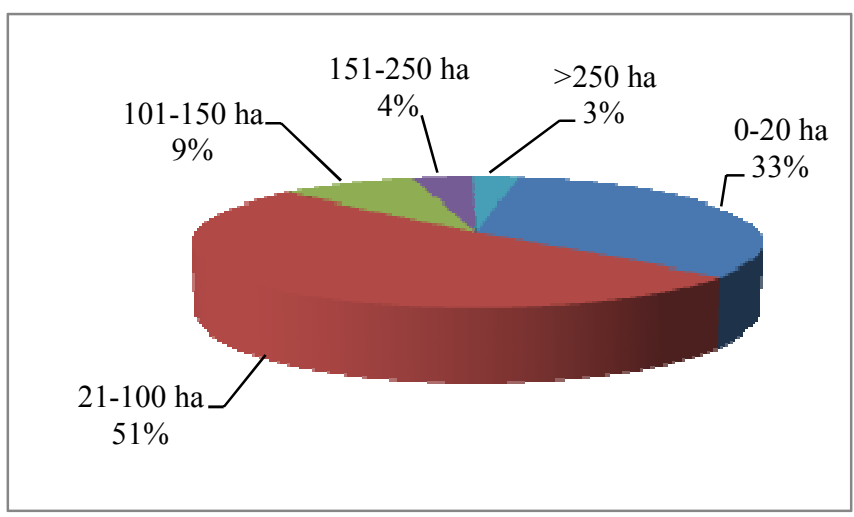

Fig. 2. Organic farming in Latvia - size of farms (ha) [prepared by authors using [32]]

From the Figure 2 data can conclude that the biggest part owned by small farms with the total area not more than 100 hectares $(84 \%)$.

The total certified agricultural area increased in 2011, reaching $10.7 \%$ of all agricultural land or 184105 ha. From all in 2011 certified farms 2866 companies were certified as organic farming companies, 186 have received the transition to organic farming certificate and 432 companies the transition period had just started.

Difficulties in the processing of organically grown products are associated with the production capacity, certification of particular products and logistics, as majority of customers concentrates in Riga, while farms are located in remote rural areas. Other challenges for organic farmers include: unstable investments and income; high agro-technical requirements; less productive business; crop rotation, high requirements for animal welfare; nutritive security; the small size of the farms and weak cooperation; monitoring, traceability, control and certification.

Organic farming sector is growing. Overall positive trend in organic farming is increasingly growing consumers' demand, which gives farmers a lot of new opportunities. Being organic farmers, the producers receive a certificate and obtain the right to market their products under the label 'organic'. As a result, healthy and natural product enters the market increasing the competitiveness of producers. The market price for organic products is higher because the consumer is willing to pay more for qualitative food, animal welfare and environmental protection. It is possible to get annual state aid for organic products.

Organic farming includes many agricultural sectors:

- crop cultivation

- livestock breeding

- beekeeping

- rearing of aquaculture animals

- wild animal breeding

- mollusc growing
- earthworm farming

- product processing

- fertilizer producing

The main production areas are crop production, including cereals and vegetables, and dairy farming. Cereal farms specialize in rye and wheat for bread baking, while oats and barley are produced for fodder, thus securing the domestic demand for organic feedstuffs. Consumer demand is highest for vegetables and fruit. The main crops are potatoes, onions, carrots and beet and, in terms of early vegetables from greenhouses, cucumbers, tomatoes and sweet peppers. In the past years there has also been a strong increase in the demand for medicinal and aromatic plants. The main types of livestock are dairy cows, beef, pigs and poultry. Different types of honey, pollen and beeswax products are also popular. Development of organic production in Latvia from 2007 to 2011 can see in Figure 3.

Outside Riga region (the capital of Latvia) the largest numbers of enterprises per 1000 inhabitants are observed in agriculture. The number of companies and farms engaged in primary processing and processing of organic farming products growing year by year. 16 companies were operational in 2007: a bakery (Kelmēni farm), three slaughterhouses (Zaubes cooperative, rabbit slaughterhouses Sveki and Šalkas - Elvi), four milk processing companies (Keipenes piensaimnieku sabiedrība, goat milk processing company Līcīši Ltd., Juri farm and JSC Trikātas siers), three tea manufacturers (Ozolini, Ragāres and Upmal̦i farms), four fruit, berries, vegetables and hemp processing companies (Pārsla - 2 Ltd., Meldri and Sidrabi farms and Latvian Cooperative Society of Dairy Farmers Latgales Ekoprodukti) and a honey processing company (Vinnis Ltd.). Three grain storage facilities, two milk collection companies as well as a packaging and sales cooperative (Zaļais grozs) were also involved in circulation of organic farming products. Nowadays the number of such companies increased. At the beginning of the 2013 there were 1266 certified organic farms in Latvia. [33]

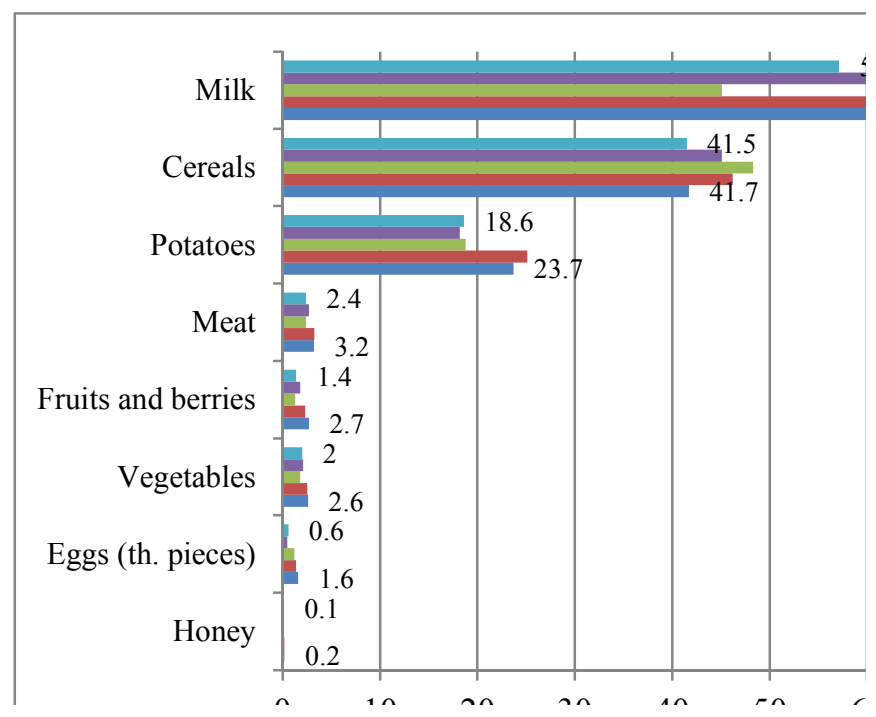

Fig. 3. Organic production in Latvia [prepared by authors using [32]] 
Certification of organic agricultural companies is performed in accordance with the requirements of „Council Regulation (EC) No 834/2007 of June 28, 2007 on organic production and labelling of organic products and repealing Regulation (EEC) No 2092/91” and „Commission Regulation (EC) No 889/2008 of 5 September 2008 laying down detailed rules for the implementation of Council Regulation (EC) No $834 / 2007$ on organic production and labelling of organic products with regard to organic production, labelling and control" and their amendments, and national laws and regulations on organic farming.

To become a producer of organic products in Latvia, an application shall be submitted at State Ltd „Certifying and Testing Centre". For production enterprises- until 1 April of the current year, for processing companies - throughout the year!

Latvian Agricultural Consulting and Educational Support Centre provide the course on organic farming (180 hours total) for education of farmers.

In order to promote marketing of organic farming products, national subsidies were granted in 2011 to support primary processing and processing of those products as well as seed farming development and establishment of a database of vegetative propagation stock. Support for primary processing and processing of products was received by farms developing and implementing projects.

The import of all types of food and agricultural products increased in 2012, amounting to more than LVL 1330 million. The value of food and agricultural goods exported in 2011 was LVL 1073.9 million and LVL 1158 million in 2012. In Latvia, the largest part of goods was exported and imported from the European Union countries. The most important export partners for Latvia in 2007 were Lithuania and Estonia, while Germany and Lithuania were the most important import partners.

The EU financially supports organic farming practices through the agrienvironment payments under the European Agricultural Fund for Rural Development (EAFRD). The agrienvironment payments are generally implemented through contracts between a public body in the Member States and a beneficiary (farmer or land manager). These contracts commit the beneficiary to apply specific farming practices. One of the farming practices beneficiaries may opt for is organic farming. By the end of 2010, public support commitment for organic agriculture under the agri-environment measures amounted to more than 690 million euro (EU-27). EAFRD support represents $58 \%$ of total public support while the remainder is comprised of national contributions.

Organic production can also be supported indirectly through other measures from the EAFRD (such as modernisation of agricultural holdings, training etc.) or through specific support. Certain Member States have prioritised giving aid to holdings or projects developing organic production. [1]

Many farmers and their associations are interested in how to access EU funds for their own farms. Many former communist States have ample institutions, though some now defunct; some of those still operative are reported to be of rather poor quality, with limited material resources and there is often a low rate of enterprise development arising from limited research on entrepreneurship and a low degree of networking. However, a variety of methods are used in most countries to deliver 'technology transfer', including group visits to farms.

During recent years, the popularity of food products produced in Latvia's organic farms has grown. The customers have also become more interested in visiting farms that offer an insight into organic farming and a unique opportunity to strengthen one's health and get some rest. "Spend a weekend at the organic farm, feed animals, taste herbal teas, enjoy a bathhouse, learn to bake bread and do various other wonderful activities," encourages the Association of Latvian Organic Agriculture.

Most of the organic farms welcome and accommodate their guests with open arms. City residents will find it interesting to become familiar with life in the countryside and participate in several rural activities - helping farmers bake bread, gather honey and take care of livestock. "Gain new emotions, as we offer you the opportunity to milk a cow," point out the owners of "Zemenu krastini" Lodge. The guests are offered a steam bath in a real countryside bathhouse. The farms also serve meals that are prepared mostly from their own organic products.

Latvian farms are surrounded by picturesque scenery, encouraging guests to make use of the opportunity and observe wild animals and hike on the most beautiful forest trails.

\section{CONCLUSIONS}

Organic agriculture is a model for rural development. Organic agriculture is demonstrating with real-life examples how to enhance economic, social and environmental sustainability. Not only rural populations enjoy the fruits of organic agriculture, urban citizens are better off as well. Therefore: Governments at local and national levels should use organic agriculture as a strategy for rural development, involving rural communities and consumers in their decisions. Local authorities can create positive conditions for developing organic agriculture in their region. This can be achieved by:

1. Organizing daily and weekly farmers' markets in cities.

2. Providing local and organic food in public canteens (schools, hospitals, etc.).

3. Promoting the establishment of eco-agro tourism.

4. Educating younger generations on the close links between agriculture, ecology and their daily food.

The development of organic agriculture in Latvia should be based on the same principles on which are based organic agriculture worldwide. Improvement of technologies isn't enough for achieving a more sustainable development and especially for organic farming systems. Changes for the whole farming system are necessary which show the multifunctional role of agriculture. We need to develop self-sufficient and selfregulating production systems, which are less dependent from artificial, industrial inputs, can use more efficiently local resources and are friendly to the environment. But this isn't enough also. 
Researches have to be undertaken for the whole food chain- from crop breeding, primary production by farmers, processing, marketing up to consumers. By saying this we mean to take in consideration not only the production sector, but also the environment and social sectors. In other words, the whole link should be in the attention of researches - from the fork up to the table of consumers.

Educational work has a crucial role in this respect. Agro ecology which is studding the ecology of the whole food chain has to be studied in agricultural universities. Farmers have to be involved in more on-farm researches for answering to direct questions raised by them. For educational purposes more model farms have to be founded where all farmers, but especially conventional ones can change their mentality. More public funds need to be allocated in doing researches education and extension works at the national and international levels. Cooperation between universities and research institutions at the international level can play a very important role in straitening the work on organic agriculture. All described above only the first step toward a more sustainable agriculture in Latvia.

\section{ACKNOWLEDGMENT}

The authors acknowledges the financial support provided by the ERAF project "Riga Technical University international cooperation, projects and capacity development in science and technology Nr. 2DP/2.1.1.2.0/10/APIA/VIAA/003" for this research.

\section{REFERENCES}

[1] "Audit of the control system governing the production, processing, distribution and imports of organic products". Special Report No 9. Luxembourg: Publications Office of the European Union, 2012. ISBN 978-92-9237-669-7. doi:10.2865/50111 / 2012

[2] Data and statistics, European Commission 3. [Accessed on 06.06.2012.] Available at: http://ec.europa.eu/agriculture/organic/home_en

[3] De Buck A.J., van Rijn I., Roling N.G., Wossink G.A.A.. "Farmers' reasons for changing or not changing to more sustainable practices: an exploratory study of arable farming in the Netherlands". J. Agr. Educ. and Exten. 2001. 7(3), 153-166.

[4] Den Biggelaar, C. and Suvedi, M. "Farmers' Definitions, Goals, and Bottlenecks of Sustainable Agriculture in the North-Ventral Region" Agriculture and Human Values. 2000. 17(4): 347-358.

[5] James, O. "Latvian farming 's from traditional methods to organic incentives" [Accessed on 20.02.2013.] Available at: http://www.baltictimes.com/news/articles/23574/

[6] Jansen K., Vellema S. "Agribusiness and Society: Corporate Responses to Environmentalism, Market Opportunities and Public Regulation". London: Zed Books. 2004.- 302 p.

[7] IFOAM. "Organic Agriculture and Rural Development". [Accessed on 26.12.2012.] Available at: http://www.ifoam.org/organic_facts/food/pdfs/Rural_Development_Leaf let_new.pdf

[8] Einarsson, P., Luttikholt, L. "Organic Agriculture and globalization". [Accessed on 29.12.2012.] Available at: http://www.ifoam.org/organic_facts/politics/pdfs/OA_Globalization_Ba ckgroundPaper.pdf

[9] FADN public database. European Commission. [Accessed on 16.11.2012.] Available http://ec.europa.eu/agriculture/rica/dwh/index_en.cfm
[10] Francis C.A., Sander D., Martin A. "Search for a sustainable agriculture: reduced inputs and increased profits". Crops Soils Mag. 1987, 39, pp. 12-14.

[11] Gafsi M., Legagneux B., Nguyen G., Robin P. "Toward sustainable farming systems: effectiveness and deficiency of the French procedure of sustainable agriculture", Agr. Sys. 2006. 90, pp.226-242.

[12] Gliessman S. "Agroecology: ecological processes in agriculture". CRC Press, Michigan. 1998.- 357 p.

[13] Gliessman S. "Agroecology: the ecology of sustainable food systems". CRC Press, 2nd ed., 2006.- 384 p.

[14] Gold M. "Sustainable agriculture: definitions and terms, Special reference briefs 99-02", USDA National Agricultural Library (NAL), 1999. ISSN 1052-5368.

[15] Ikerd "The need for a system approach to sustainable agriculture". Agr. Ecosyst. Environ. 1993. 46, pp.147-160.

[16] Hansen. "Is agricultural sustainability a useful concept?" Agr. Syst. 1996. 50, pp.117-143.

[17] Hansen J.W., Jones J.W. "A systems framework for characterizing farm sustainability". Agr. Syst. 1996. 51, pp.185-201.

[18] Hunek T. "Convergence of Agriculture in The Market Oriented Economy". [in:] Rosner A. (ed.): Problems of Village and Agriculture during Market Reorientation of the Economy. IRWiR PAN, Warsaw, 2004. pp. 45-59.

[19] Larssona, M., Granstedt A. "Sustainable governance of the agriculture and the Baltic Sea - Agricultural reforms, food production and curbed eutrophication". Ecological Economics. 2010. 69. pp. 1943-1951

[20] Legrand P., Fraval A., Laurent C. "INRA faced with Sustainable Development": Landmarks for the Johannesburg Conference (English version), Dossiers de l'Environnement de l'INRA n॰22, Paris, 212 p., INRA Éditions, ISBN: 2-7380-1049-0 . [Accessed on 20.01.2013.] Available at: http://www.inra.fr/dpenv/do22-e.htm

[21] Lockeretz W. "Organic farming: an international history". Wallingford: CABI. 2007. 282 p.

[22] Niggli, U. "High sequestration, low emission, food secure farming - the potential of organic agriculture for climate change mitigation".2009. [Accessed on 25.01.2013.] Available at: http://www.ifoam.org/about_ifoam/around_world/eu_groupnew/news/pdf/100420-Organicday-1.pdf

[23] "Organic agriculture". [Accessed on 30.01.2013.] Available at: http://ifoam.org/growing_organic/definitions/doa/index.html

[24] "Organic farming”. [Accessed on 30.01.2013.] Available at: // http://ec.europa.eu/agriculture/organic/organic-farming/what-organic_en

[25] Park, J., Seaton, R.A.F. "Integrative research and sustainable agriculture”. Agricultural Systems. 1996. 50, pp.81-100.

[26] Prus P. "Sustainable development of individual farms based on chosen groups of farmers". EJPAU. 2008. 11(3), \#06.

[27] Shaller, N. "The concept of agricultural sustainability". Agriculture, Ecosystems and Environment 1993. 46, 89-97.

[28] "The Principles of Organic Agriculture" [Accessed on 24.02.2013.] Available http://www.ifoam.org/about_ifoam/principles/index.html

[29] "The Structure of Agricultural Farms of Latvia in 4. June 2007. Central Statistical Bureau of Latvia. Riga, 2008. P.76.

[30] Tambovceva, T., Geipele, I. "Sustainable agriculture in Latvia". Ekonomika ir vadyba: aktualijos ir perspektyvos. 2009. 2 (15), pp. 286294.

[31] Tilman D., Cassman K.G., Matson P.A., Naylor R., Polasky S. "Agricultural sustainability and intensive production practices". Nature 2002. 418, pp.671-677.

[32] Lauksaimniecības gada ziņojumi. [Accessed on 28.01.2013.] Available at: http://www.zm.gov.lv/?sadala=739

[33] Sertificēto uzn̄ēmumu saraksts. . [Accessed on 28.03.2013.] Available at: http://www.stc.lv/lv/pakalpojumi/biologiskas-lauksaimniecibasuznemumu-sertifikacija/sertificeto-uznemumu-saraksts/

\section{Creative Commons Attribution License 4.0 (Attribution 4.0 International, CC BY 4.0)} This article is published under the terms of the Creative
Commons Attribution License 4.0

https://creativecommons.org/licenses/by/4.0/deed.en_US 